\title{
Tradisionalitas dan Modernitas Dikotomi Perkembangan Wilayah Pesisir Kabupaten Gunungkidul
}

\section{Traditionality and Modernity Dichotomy of Gunungkidul Regency Coastal Region Development}

\author{
*Arie Nurzaman ${ }^{1}$ ), Muhammad Sani Roychansyah ${ }^{1}$ )* \\ 1) Magister Perencanaan Wilayah dan Kota, Fakultas Teknik, \\ Universitas Gadjah Mada Yogyakarta, Indonesia \\ Diterima: Februari 2020; Disetujui: April 2020; Dipublikasi: 31 April 2020 \\ *Corresponding author: E-mail : arienz.81@gmail.com
}

\begin{abstract}
Abstrak
Pola aktivitas dan penggunaan ruang dipengaruhi oleh banyak faktor, termasuk ekonomi, sosial, budaya, atau sejarah. Daerah pedesaan yang umumnya didominasi oleh daerah tertinggal menjadi korban eksploitasi manusia dalam hal pemanfaatan ruang, termasuk wilayah pesisir. Oleh karena itu, pemanfaatan dan pengembangan wilayah pesisir dan masyarakat yang tinggal di kawasan tersebut membutuhkan pendekatan yang tepat. Dikotomi ruang perlu dipahami sebagai aspek pengembangan wilayah pesisir itu sendiri. Makalah ini bertujuan untuk menilai pola pemanfaatan ruang, dikotomi antara aspek tradisional dan modern dalam pemanfaatan ruang, serta kemungkinan strategi dan kebijakan pengembangan pemerintah wilayah pesisir di Kabupaten Gunungkidul. Metode ini merupakan kombinasi dari metode kuantitatif yang dilaksanakan dengan meninjau peta dan analisis data sekunder untuk melihat tren perkembangan dalam periode tertentu, sedangkan metode kualitatif dilakukan untuk memperkuat hipotesis dan untuk memahami analisis lebih lanjut dari pendekatan kuantitatif.

Dikotomi ruang dijabarkan dalam konteks spasial dan pemanfaatan. Konteks spasial dibagi menjadi wilayah inti (ibukota kecamatan) dan pinggiran (wilayah pesisir), sedangkan dalam konteks pemanfaatan ruang, dibedakan menjadi penggunaan tradisional dan modern. Analisis dikotomi melalui penggambaran kuadran memberikan gambaran tentang potensi pembangunan daerah, ruang lingkup pembangunan tidak hanya sebagian tetapi juga secara spasial. Pengembangan Jaringan Jalan Nasional Jawa Selatan (JJLS) dan pengembangan sektor pariwisata adalah dua faktor utama dalam pembangunan daerah, sehingga kebijakan publik sebagai implementasi dari intervensi pemerintah setidaknya harus mempertimbangkan sektor spesifik yang akan ditangani, prioritas pembangunan seperti skala dan pendekatan, dan tingkat perkembangan.

Kata Kunci: dikotomi; tradisional; modern; Gunungkidul; wilayah pesisir
\end{abstract}

\begin{abstract}
The pattern of activity and use of space is influenced by many factors, including economic, social, cultural, or historical. Rural areas that are generally dominated by disadvantaged areas are victims of human exploitation in terms of spatial use, including coastal areas. Therefore, the use and development of coastal areas and the people who live in these areas need the right approach. The space dichotomy needs to be understood as an aspect of developing the coastal region itself. This paper aims to assess the pattern of spatial use, the dichotomy between traditional and modern aspects of spatial use, as well as possible strategies and policies for the development of coastal regional governments in Gunungkidul Regency. This method is a combination of quantitative methods which are carried out by reviewing maps and secondary data analysis to see development trends in a certain period, while qualitative methods are used to strengthen
\end{abstract}


hypotheses and to understand further analysis of quantitative approaches. The spatial dichotomy is described in spatial and utilization contexts. Spatial contexts are divided into core areas (subdistrict capital) and periphery (coastal areas), while in the context of spatial use, they are divided into traditional and modern uses. Analysis of the dichotomy through quadrant depiction provides an overview of the potential for regional development, the scope of development not only partially but also spatially. The development of the South Java National Road Network (JJLS) and the development of the tourism sector are the two main factors in regional development, so public policy as an implementation of government intervention must at least consider the specific sectors to be addressed, development priorities such as scale and approach, and the level of development. Keywords: dichotomy; traditional; modern; Gunungkidul; coastal region

How to Cite : Nurzaman A, M. Sani Roychansyah, (2020), Tradisionalitas dan Modernitas dikotomi Perkembangan Wilayah Pesisir Kabupaten Gunungkidul, Journal of Architecture and Urbanism Research, 3 (2): Hal 104-115. 



\section{PENDAHULUAN}

Pertumbuhan penduduk yang tinggi dan pesatnya kegiatan pembangunan di pesisir dengan berbagai peruntukannya (permukiman, industri, perikanan, pelabuhan, pariwisata, pertambangan, dan lain-lain) telah menyebabkan peningkatan tekanan ekologis terhadap ekosistem pesisir. Hal ini tentunya dapat mengancam keberadaan dan kelangsungan ekosistem dan sumberdaya pesisir, baik secara langsung (misalnya kegiatan konversi lahan) maupun tidak langsung (misalnya pencemaran oleh limbah berbagai kegiatan pembangunan).

Menurut Dahuri, dkk. (2008) batas wilayah pesisir ke arah darat adalah jarak secara arbitrer dari rata-rata pasang tinggi (mean high tide), dan batas ke arah laut adalah batas yurisdiksi wilayah propinsi atau state di suatu Negara. Wilayah pesisir mencakup wilayah daratan sejauh masih mendapat pengaruh laut (pasang surut dan perembasan air laut pada daratan) dan wilayah laut sejauh masih mendapat pengaruh dari darat (aliran air sungai dan sedimen dari darat). Definisi lain dikemukakan oleh Cahyadinata (2009) yang menjelaskan tentang kawasan pesisir, yaitu daerah peralihan/transisi antara ekosistem daratan dan lautan. Kawasan ini ke arah darat mencakup daerah yang masih dipengaruhi oleh proses-proses kelautan, seperti pasang surut, intrusi air laut, gelombang, dan angin laut, dan ke arah laut meliputi daerah perairan laut yang masih dipengaruhi oleh proses-proses daratan dan dampak kegiatan manusia, seperti aliran air sungai, sedimentasi, dan pencemaran.

Djunaedi, dkk (2002) menyampaikan bahwa wilayah pantai/pesisir mempunyai karakter yang spesifik dan merupakan agregasi dari berbagai komponen ekologi dan fisik yang saling terkait dan saling mempengaruhi, serta secara ekologis sangat rapuh. Tidak dapat dipungkiri bahwa keberadaan wilayah pesisir yang memiliki ragam potensi sumberdaya alam sekaligus merupakan ekosistem yang rentan akan selalu bersinggungan dengan perkembangan pola aktifitas manusia. Oleh karena itu, pemanfaatan dan pengembangan ruang pesisir termasuk mempertimbangkan aspek kehidupan sosial masyarakat di wilayah tersebut perlu pendekatan yang tepat. Dikotomi ruang pesisir perlu dipahami sebagai salah satu aspek pengembangan entitas ruang pesisir.

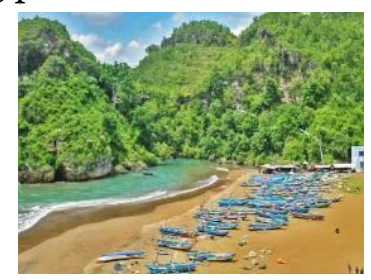

Gambar 1. Kegiatan Perikanan di Pantai Baron,Gunungkidul

(sumber: Dinas Kelautan dan Perikanan Gunungkidul, 2014).

Adapun Tujuan dari penelitian ini adalah (a) Mengetahui pola pemanfaatan ruang wilayah pesisir Kabupatan Gunungkidul, (b) Mengetahui dikotomi ruang tradisional dan modern di wilayah pesisir Kabupaten Gunungkidul (c) Mengetahui potensi pengembangan wilayah pesisir Kabupaten Gunungkidul

\section{METODE PENELITIAN}

Metode yang digunakan adalah gabungan antara metode kuantitatif dan kualitatif. Keduanya diharapkan dapat memberikan gambaran terhadap fenomena yang diteliti. Metode kuantitatif dilakukan dengan melihat trend perkembangan dalam periode tertentu berdasarkan data-data eksisting yang diperoleh dari peta, dokumentasi lapangan maupun data sekunder. Metode kualitatif dilakukan guna memperkuat hipotesis dan merupakan 
analisis lanjut dari pendekatan kuantitatif. Secara lebih rinci dapat dilihat dalam tabel berikut.

Tabel 1. Perbandingan kedua metode.

\begin{tabular}{lrl}
\hline Kuantitatif & \multicolumn{1}{c}{ Kualitatif } \\
\hline $\begin{array}{l}\text { Menyediakan } \\
\text { (existing) }\end{array}$ & data & Analisis lanjut \\
$\begin{array}{l}\text { Melihat trend (time } \\
\text { series) }\end{array}$ & $\begin{array}{l}\text { Menjelaskan hubungan } \\
\text { antar issue (tradisional } \\
\text { vs modern) }\end{array}$ \\
$\begin{array}{l}\text { Memberikan gambaran } \\
\text { obyektif }\end{array}$ & Memperkuat hipotesis \\
\hline $\begin{array}{l}\text { Sumber: Data penulis, } \\
2017\end{array}$ & \\
\hline
\end{tabular}

\section{PEMBAHASAN}

Wilayah Pesisir Kabupaten Gunungkidul, menurut van Bemmelen (1949), topografi wilayah pesisir Gunungkidul berupa pegunungan terjal yang berada di dalam rangkaian Pegunungan Selatan. Daerah yang berada di dalam rangkaian Pegunungan Selatan memperlihatkan satuan geomorfik bentukan asal karst, dan vulkanik terdenudasi. Satuan geomorfik bentukan asal karst dicirikan dengan bentuk lahan berupa perbukitan karst dengan kenampakan kerucut karst (conical karst) dan lembah kering (dry valley), mencakup Kecamatan Girisubo, Tepus, Tanjungsari, Saptosari, Panggang, dan sebagian Purwosari. Bentukan asal karst memiliki ciri pantai berupa pantai tebing.

Wilayah pesisir Kabupaten Gunungkidul memiliki luas 1.023,10 km2 dengan batas wilayah ke arah laut sejauh 4 mil dan ke arah darat sampai batas wilayah kecamatan yang mempunyai garis pantai. Wilayah ini terdiri dari 6 kecamatan yaitu Purwosari, Panggang, Saptosari, Tanjungsari, Tepus, dan Girisubo. Wilayah pesisir kabupaten Gunungkidul memiliki sempadan pantai seluas kurang lebih 770 (tujuh ratus tujuh puluh) hektar terletak di sepanjang dataran Pantai Selatan Gunungkidul dengan daerah selebar minimum 100 (seratus) meter dari titik pasang tertinggi ke arah darat dan seluas $514 \mathrm{Km}^{2}$ yang terdiri dari 6 kecamatan, 36 desa dan 373 dusun. Jumlah penduduk di wilayah kecamatan pesisir (6 kecamatan) sebanyak 166.692 jiwa atau 23,6\% dari jumlah penduduk Kabupaten Gunungkidul, dengan rata-rata kepadatan 316 jiwa $/ \mathrm{km}^{2}$ (GDA, 2016).

Kabupaten Gunungkidul dilalui oleh Jaringan Jalan Kolektor Primer sebagai jaringan strategis yang diberi nama Jaringan Jalan Lintas Selatan (JJLS) yang direncanakan mencapai panjang 81,092 km (Bappeda Gunungkidul, 2016). Sebagian besar jaringan jalan tersebut telah selesai dan berfungsi optimal khususnya sebagai jalur penghubung wilayah selatan Gunungkidul dan Bantul.

Wilayah selatan Gunungkidul memiliki karakter geomorfologi yang unik berupa bentang alam karst. Karakter ekosistem karst yang memiliki lapisan atas berupa tanah yang tipis dan tidak dapat menyimpan air dalam waktu yang lama menyebabkan kegiatan pertanian terbatas pada budidaya tanaman palawija dan tanaman keras. Penduduk setempat juga memanfaatkan potensi karst dengan melakukan penambangan batu kapur. Berdasarkan ketetapan UNESCO dalam konferensi Asia Pasific Global Network di Jepang pada tanggal 19 September 2015 kawasan karst Gunung Sewu (Gunung Seribu) masuk dalam Geopark Internasional (Global Geopark) atau situs warisan dunia. Jaringan geopark dunia (Global Geopark Network) tidak hanya meliputi rangkaian pegunungan karst di Kabupaten Gunungkidul namun juga membentang hingga Kabupaten Wonogiri (Jawa Tengah) dan Kabupaten Pacitan (Jawa Timur). 
Dikotomi Inti-Pinggiran dan TradisionalModern, pembahasan dikotomi ruang dijabarkan dalam konteks spasial dan konteks pemanfaatan. Secara spasial dibedakan menjadi wilayah inti dan pinggiran. Wilayah inti direpresentasikan melalui wilayah ibukota kecamatan pesisir, sedangkan wilayah pinggiran adalah wilayah sekitar pantai. Analisis kedua yakni dalam konteks pemanfaatan ruang, dibedakan menjadi pemanfaatan secara tradisional dan secara modern. Keempatnya digambarkan dalam sebuah kuadran, dimana masing-masing kuadran memiliki karakteristik tersendiri.

Dalam konteks spasial, wilayah pesisir yang menjadi area penelitian dibagi menjadi dua, yakni wilayah ibukota kecamatan (inti) dimana secara umum didominasi permukiman penduduk dan pusat kegiatan ekonomi, sedangkan wilayah sekitar pantai (pinggiran) pada umumnya didominasi kegiatan perikanan dan pariwisata.

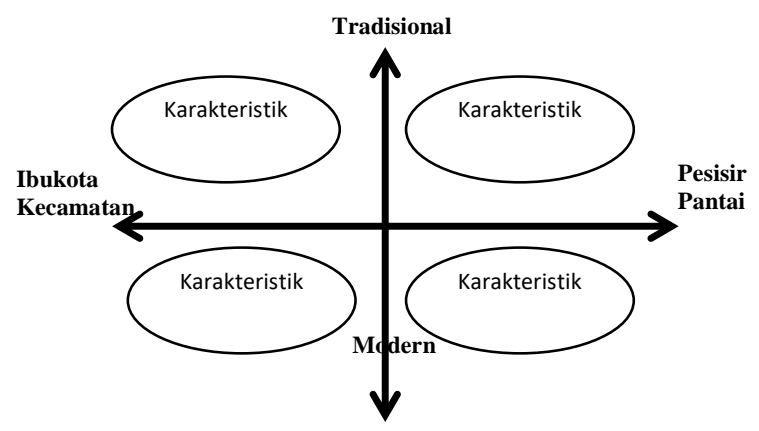

Diagram 1. Konsep Dualisme

(sumber: Analisis data penulis, 2017).

Untuk dapat memahami pengertian pemanfaatan ruang secara tradisional dan modern, berikut dijelaskan kedua definisi tersebut menurut Kamus Besar Bahasa Indonesia (KBBI), yakni :

a. Tradisional yaitu (1) sikap dan cara berpikir serta bertindak yg selalu berpegang teguh pd norma dan adat kebiasaan yg ada secara turun-temurun: daerah itu mempunyai potensi cukup besar di bidang perikanan, tetapi masih diolah secara --; (2) menurut tradisi (adat): upacara -- , upacara menurut adat

b. Modern yaitu (1) a terbaru; mutakhir: pasukan diperlengkapi dng senjata-senjata -; (2) $n$ sikap dan cara berpikir serta cara bertindak sesuai dng tuntutan zaman.

Analisis Dualisme, atau dalam artikel ini digunakan kata dikotomi menurut KBBI didefinisikan sebagai pembagian atas dua kelompok yang saling bertentangan. Sedangkan definisi ruang menurut UU No. 26 Tahun 2007 tentang Penataan Ruang adalah wadah yang meliputi ruang darat, ruang laut, dan ruang udara, termasuk ruang di dalam bumi sebagai kesatuan wilayah, tempat manusia dan makhluk hidup lain hidup, melakukan kegiatan, dan memelihara kelangsungan hidupnya.

Dalam konteks keruangan, dikotomi dapat diartikan sebagai pemisahan entitas ruang yang mencakup komponen yang melekat di dalamnya. Konsep dikotomi dapat dipengaruhi oleh beberapa faktor, diantaranya:

a. Faktor sifat ruang seperti alamibuatan

b. Faktor fungsi seperti publik-privat dalam pembagian fungsi ruang.

c. Faktor karakteristik ruang seperti terbangun-tidak terbangun

Dalam hal ini, masing-masing kuadran memiliki karakteristik yang berbeda-beda dan menggambarkan fenomena yang unik dan apabila dicermati melalui sudut pandang hubungan sosial ekonomi masyarakat, tampak bahwa pola pemanfaatan ruang sangat erat kaitanya dengan pola aktivitas dan cara pandang manusia.

Pada kuadran inti-tradisional, terlihat bahwa karakteristik yang dominan berupa pemanfaatan ruang permukiman dan lahan 
pertanian secara tradisional. Ibukota kecamatan sebagai wilayah inti, pada awalnya merupakan pusat pemerintahan lokal dimana kepala pemerintahan menjalankan fungsi administrasinya. Pemanfaatan ruang untuk tempat tinggal dan kegiatan pertanian secara tradisional tampak dari bentuk bangunan rumah yang sebagian besar merupakan rumah adat Jawa, baik dari segi fisik bangunan maupun filosofinya. Pola aktivitas pertanian juga masih dilakukan secara tradisional karena kondisi tanah berupa karst yang minim sumber air permukaan, sehingga ketergantungan terhadap sumber air hujan sangat tinggi. Karakteristik lain yang masih menonjolkan tradisionalitas adalah kearifan lokal yang dimanifestasikan dalam bentuk simbol maupun ritual, seperti penggunaan ornamen lokal pada bangunan, kegiatan kenduri, ruwatan, maupun penerapan pranata mangsa dalam bercocok tanam.

Kuadran inti-modern ditunjukkan dengan lebih berkembangnya pusat pemerintahan sebagai pusat kegiatan lokal.
Pemanfaatan ruang lebih beragam seperti bangunan pemerintahan, pendidikan, kesehatan, ekonomi, olahraga, dan hiburan dilengkapi dengan fasilitas yang modern. Sebagai contoh, ibukota kecamatan Panggang merupakan pusat kegiatan lokal dimana terdapat kantor kecamatan, sekolah dasar, sekolah menengah, Puskesmas, pasar, perbankan, dan terminal. Jaringan internet, telekomunikasi, dan ATM juga tersedia, bahkan mulai muncul minimarket modern.

Kuadran selanjutnya, yaitu pinggirantradisional lekat dengan kegiatan pertanian dan perikanan. Area di sekitar JJLS didominasi lahan yang belum terbangun, berupa tanah pertanian dan tegalan, sedangkan kegiatan perikanan dengan menggunakan alat dan metode tradisional juga masih dapat ditemui. Nelayan darat yang menangkap lobster dan kepiting masih menggunakan alat tangkap sederhana yang disebit krendet, berupa rangkaian jaring dan besi yang berbentuk lingkaran dan ditempatkan di dasar perairan yang dangkal.

Tabel 2. Karakteristik tiap kuadran

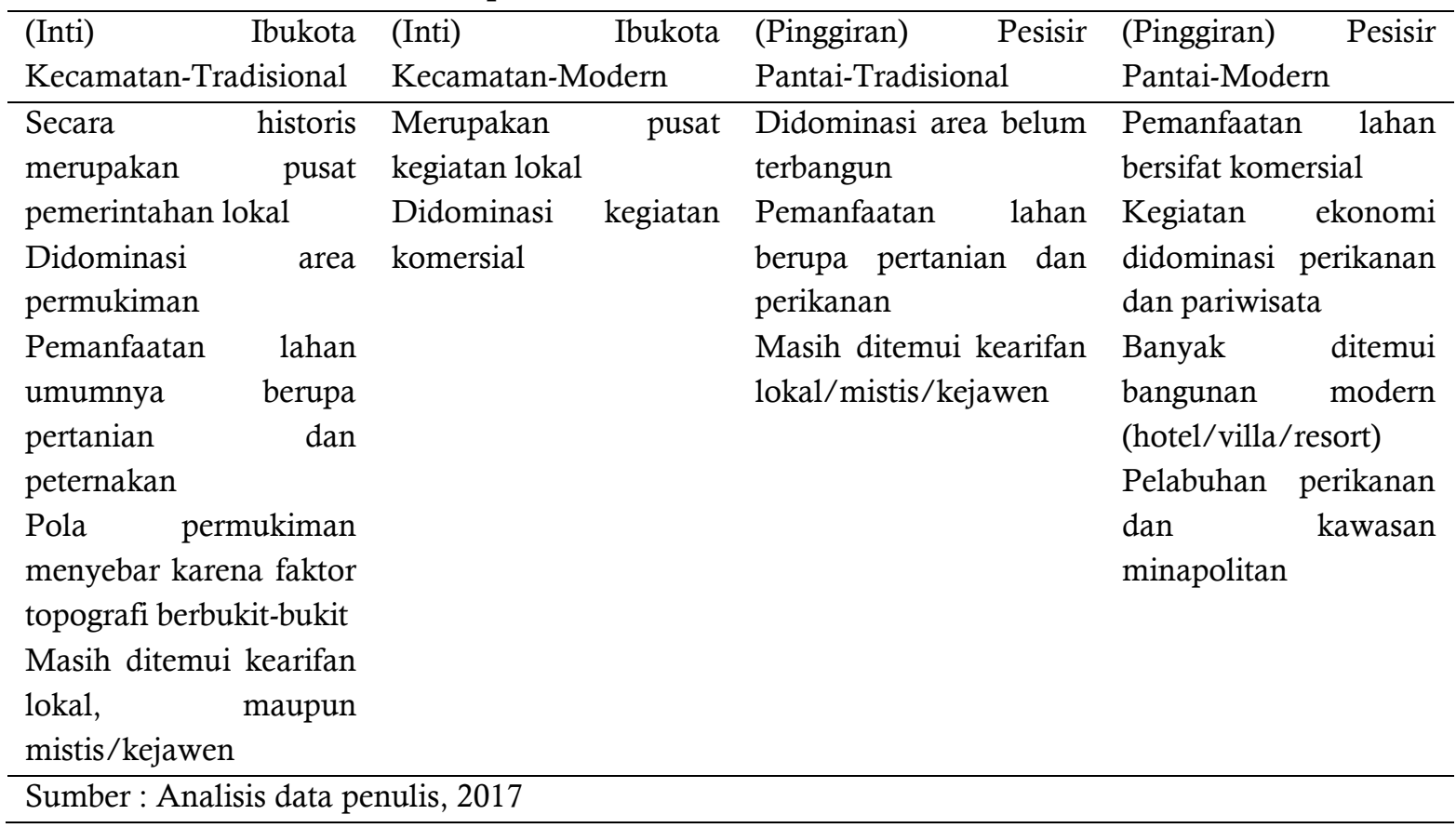


Demikian pula dengan penduduk yang mencari rumput laut secara tradisional, menggunakan gancu pada saat air laut surut. Penerapan pranata mangsa dalam kegiatan perikanan juga masih kental. Selain itu, ada pula kearifan lokal dalam menjaga lingkungan pesisir dan laut dengan adanya upacara adat seperti sedekah laut ataupun ngalangi di Pantai Wediombo sebagai bentuk penghayatan masyarakat terhadap hubungan masnusia dengan alam.

Kuadran pinggiran-modern sebagai dikotomi yang terakhir dicirikan dengan pemanfaatan lahan secara komersial, kegiatan yang ada didominasi oleh kegiatan pariwisata dan perikanan, serta adanya bangunan modern seperti hotel, villa, dan resort. Sebagai contoh di beberapa pantai yang merupakan destinasi pariwisata populer seperti pantai Kukup, Pantai Krakal, Pantai Sundak, dan sekitar Pantai Indrayanti telah tumbuh berbagai macam fasilitas pendukung pariwisata seperti penginapan dan restoran. Hampir semua akomodasi tersebut dilengkapi dengan fasilitas yang modern yang menunjukkan perkembangan pariwisata di wilayah selatan Gunungkidul. Modernisasi di sekor perikanan tampak dari berkembangnya alat dan metode yang digunakan nelayan, misalnya penggunaan perahu yang lebih besar, alat tangkap yang beragam, dan penggunaan teknologi GPS maupun informasi cuaca berbasis aplikasi komputer. Adanya pelabuhan perikanan di Pantai Sadeng dan pengembangan kawasan minapolitan juga merupakan bentuk perkembangan pemanfaatan ruang pesisir secara modern mengingat sebelumnya sentra perikanan berupa beberapa desa nelayan kecil yang tersebar.

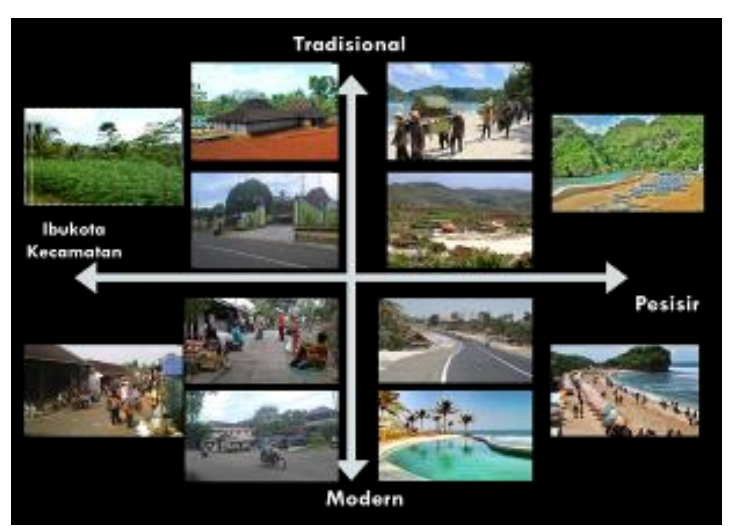

Gambar 2. Contoh pemanfaatan lahan dalam kuadran dikotomi

(sumber: Analisis data penulis, 2017).

\section{Pada Konsep Pengembangan, Potensi dan}

Arah perkembangan, dalam konteks dikotomi, pemanfaatan lahan di wilayah pesisir Gunungkidul selama ini lebih banyak didominasi kegiatan perikanan dan pariwisata. Potensi perikanan mulai dikembangkan pada awal tahun 80an dimana pada saat itu terdapat Pantai Baron yang merupakan pusat kegiatan perikanan tangkap di Gunungkidul. Beberapa tahun kemudian, pemerintah kabupaten dan propinsi mulai mengembangkan kegiatan perikanan tangkap di beberapa titik pantai lainnya. Hingga saat ini terdapat 8 titik pantai yang merupakan sentra kegiatan nelayan dan 1 pelabuhan perikanan pantai di Sadeng, Girisubo. Seiring dengan perkembangan infrastruktur jalan menuju pantai, berkembang pula kegiatan pariwisata pantai sehingga beberapa pantai di Kabupaten Gunungkidul mulai dikenal karena menawarkan keindahan panorama laut, batu karang dan pasir putih. Perkembangan pariwisata di Gunungkidul mulai menggeliat sekitar tahun 2010 dengan berkembangnya kawasan pantai Indrayanti dan sejak saat itu memicu perkembangan wisata di beberapa pantai lain di Gunungkidul diikuti dengan tumbuhnya fasilitas pendukung seperti hotel dan restoran. 
Pembangunan JJLS turut memicu pesatnya perkembangan di wilayah selatan Gunungkidul karena mobilitas masyarakat dan distribusi barang dan jasa antar kabupaten menjadi lebih tinggi. Hal ini sesuai dengan tujuan dibangunnya JJLS sebagai penghubung wilayah selatan Pulau Jawa dan meningkatkan kegiatan ekonomi wilayah dengan harapan dapat mengurangi ketimpangan antar daerah. Beberapa kecamatan di wilayah selatan Gunungkidul saat ini mulai mengalami perkembangan sebagai dampak adanya jalan tersebut, seperti Kecamatan Panggang, Saptosari, dan Girisubo. Satu aspek lain yang mempengaruhi perkembangan pola ruang di wilayah selatan Gunungkidul adalah faktor geomorfologi wilayah berupa bentang alam karst. Selama berpuluh-puluh tahun, kondisi tersebut turut membentuk pola aktifitas dan pemanfaatan ruang masyarakat setempat.

Dalam kaitannya dengan struktur ekonomi suatu wilayah, Todaro (2000) mengatakan bahwa proses pertumbuhan ekonomi mempunyai kaitan erat dengan perubahan struktural dan sektoral. Beberapa perubahan komponen utama struktural ini mencakup pergeseran secaraperlahan-lahan aktifitas pertanian ke sektor nonpertanian dan dari sektor industri ke sektor jasa. Suatu wilayah yang sedang berkembang proses pertumbuhan ekonominya akan tercermin dari pergeseran sektor ekonominya. Yaitu tercermin dari pergeseran sektor ekonomi tradisional dimana sektor pertanian akan mengalami penurunan di satu sisi dan peningkatan peran sektor nonpertanian di sisi lainnya.

Seperti banyak kasus di wilayah lain, permasalahan yang sering dihadapi oleh sebagian besar wilayah pedesaan adalah tingkat pendapatan yang rendah meskipun sebenarnya kaya akan potensi sumber daya. Banyak masyarakat Gunungkidul yang kemudian merantau guna memperbaiki taraf hidupnya. Ketimpangan antara perkotaan dan pedesaan yang cukup besar perlu diselesaikan melalui program pengembangan pedesaan yang terintegrasi, berbasis pada lingkup kawasan, serta bersifat berkelanjutan. Beberapa aspek yang mungkin untuk dikembangkan antara lain melalui peningkatan infrastruktur, pembangunan ekonomi, dan pengembangan modal sosial, dengan mendorong kolaborasi pemerintah bersama masyarakat dan swasta.

Strategi Pengembangan, dengan Intervensi pemerintah melalui kebijakan publik menjadi penting mengingat perkembangan wilayah tidak dapat diserahkan begitu saja kepada mekanisme pasar, sehingga diperlukan konsep dan strategi pengembangan yang komprehensif dan terintegrasi berbasis kearifan lokal.

Secara spasial, konsep desentralisasi berupa pendelegasian wewenang dan peran yang lebih besar pada pemerintahan di tingkat lokal akan berimplikasi pada masifnya pembangunan di tingkat desa. Konsep pengembangan tersebut menjadikan desa sebagai penggerak pertumbuhan, sehingga peningkatan kapasitas masyarakat dan pemerintah perlu diperkuat mengingat sumber pertanian dan sumber daya alam lainnya, yang menjadi energi dari pembangunan nasional berada pada kawasan perdesaan.

Menurut Porter (1996) dalam sebuah artikel yang dimuat di Harvard Business Review yang berjudul What is Strategy? menjelaskan esensi dari stategi adalah positioning dan diferenciation, artinya pelaku bisnis harus mengetahui potensi yang dimilikinya untuk menentukan posisi mereka dalam persaingan pasar dikombinasikan dengan berbagai pilihan stategi untuk mencapai tujuan. Untuk 
mewujudkannya perlu adanya positioning, diferenciation, dan branding, guna memperkuat posisi dalam persaingan dan memperluas pasar (www.yuswohady.com).

Bidang Pengembangan, Pemerintah Daerah Gunungkidul melalui dokumen Rencana pembangunan Jangka Menengah (RPJMD) 2016-2021 dan Perda No 6 Tahun 2011 tentang Rencana Tata Ruang Wilayah Kabupaten Gunungkidul telah menjabarkan visi pembangunan yang bertujuan mewujudkan wilayah Kabupaten Gunungkidul sebagai pusat pengembangan usaha yang bertumpu pada pariwisata, pertanian, perikanan, kehutanan dan sumber daya lokal untuk mendukung destinasi wisata menuju masyarakat yang berdaya saing, maju, mandiri dan sejahtera. Wilayah Kabupaten Gunungkidul yang cukup luas memiliki potensi pariwisata sebagai salah satu modal pengembangan wilayah, mengingat efek berganda yang ditimbulkan dari sektor tersebut sangat luas. Sejak tahun 2011-2015, sektor pariwisata memberikan kontribusi yang cukup besar terhadap PAD kabupaten. Hal ini tampak pada peningkatan PAD yaitu $R p$ 2.283366.631,00 (2011), $\quad \mathrm{Rp}$ 3.464.755.588,00 (2012), $\quad \mathrm{Rp}$ 7.524.531.942,00 (2013), $\quad \mathrm{Rp}$ 15.420.475.427,00 (2014) dan $\mathrm{Rp}$ 20.980.945.431,00 (2015) (Dinas Pariwisata DIY, 2106). Jumlah kunjungan wisatawan juga mengalami peningkatan dalam 5 tahun terakhir, sebuah trend yang menggembirakan dan patut menjadi perhatian. Tingginya angka tersebut akan mendorong tumbuhnya pembangunan fasilitas pendukung pariwisata serta menggerakkan ekonomi lokal.
Tabel. 3. Jumlah kunjungan wisatawan ke Gunungkidul

\begin{tabular}{llll}
\hline & $\begin{array}{l}\text { Jumlah } \\
\text { Wisatawan } \\
\text { Tahun }\end{array}$ & $\begin{array}{l}\text { Jumlah } \\
\text { Wissatawan } \\
\text { Dameanegara }\end{array}$ & $\begin{array}{l}\text { Jumlah } \\
\text { Dotal }\end{array}$ \\
\hline 2011 & 1,299 & 615,397 & 616,696 \\
2012 & 1,800 & 998,587 & $1,000,387$ \\
2013 & 3,751 & $1,333,687$ & $1,337,438$ \\
2014 & 3,060 & $1,952,757$ & $1,955,817$ \\
2015 & 4,125 & $2,638,634$ & $2,642,759$ \\
\hline \multirow{3}{*}{ Total } & 14,035 & $7,539,062$ & $7,553,097$ \\
\hline \multicolumn{5}{c}{ Sumber : Statistik Pariwisata DIY, 2016 }
\end{tabular}

Hal ini menegaskan posisi sektor pariwisata sebagai penggerak ekonomi wilayah, didukung dengan potensi dari sektor pertanian, perikanan, peternakan, dan lainnya. Pemerintah Kabupaten Gunungkidul juga telah menetapkan beberapa Kawasan strategis Pariwisata (KSP) yaitu pengembangan potensi wisata berbasis kawasan dengan mengangkat karakteristik masing-masing kawasan. Ada 3 KSP yang berada di wilayah pesisir Gunungkidul, yakni :

1) KSP I, berupa kawasan pengembangan pariwisata berbasis alam pantai dengan pendukung wisata budaya, terletak di wilayah Kecamatan Purwosari, Panggang, dan Saptosari.

2) KSP II, berupa kawasan pengembangan pariwisata berbasis alam pantai dengan pendukung wisata olahan hasil laut, terletak di Kecamatan Tanjungsari dan Tepus.

3) KSP III, berupa kawasan pengembangan pariwisata berbasis alam pantai dengan pendukung wisata konservasi, pendidikan, dan petualangan, terletak di Kecamatan Tepus dan Girisubo. 
Dalam segi tata ruang, perlu adanya zonasi kawasan sehingga pembangunan akomodasi dan fasilitas pariwisata yang bersifat modern, seperti hotel, resort, villa, restoran, rest area, terminal, pusat hiburan, dll., dapat tertata, selain itu diperlukan juga pengembangan desa wisata guna menggerakkan ekonomi lokal dan mengangkat nilai-nilai tradisional. Wisatawan dapat diajak untuk menikmati suasana alam pedesaan dan merasakan tardisionalitas dalam konsep pengembangan desa wisata.

Potensi lain yaitu dengan adanya Gunungsewu Global Geopark (GGG), dimana ekosistem karst merupakan salah satu ekosistem yang langka dan unik dan merupakan situs warisan dunia dapat dijadikan sebagai modal menarik pasar yang lebih luas seperti kalangan pelajar, mahasiswa peneliti, ataupun wisatawan luar negri. Konsep tersebut merupakan langkah positioning dan differentiation dan branding yang dapat menggabungkan nilai tradisional dan modern sehingga memunculkan keunggulan komparatif bagi Gunungkidul.

Prioritas Pengembangan, Konsep pengembangan wilayah menurut Stohr \& Taylor pada dasarnya dapat dibagi menjadi tiga, yaitu: konsep pengembangan dari atas (development from above), konsep pengembangan dari bawah (development from below) dan konsep pengembangan ekonomi lokal (local economic development). Perubahan paradigma perencanaan dari top-down menjadi bottom-up merupakan terobosan baru yang lebih mengedepankan kepentingan publik di bandingkan kepentingan politik, karena dalam bottom-up planning masyarakat merupakan mitra pemerintah dalam penataan ruang. Oleh karena itu peran sertanya dalam setiap tahapan perlu dikembangkan demi tercapainya tujuan perencanaan (www.mie2gination.wordpress.com).

Dalam konteks pariwisata, pengembangan bertujuan untuk mengembangkan produk, baik barang dan jasa serta layanan yang berkualitas, seimbang dan bertahap. Secara spesifik, pengembangan sektor pariwisata bertujuan untuk memberikan keuntungan bagi pengunjung maupun masyarakat setempat. Pengembangan tersebut hendaknya memperhatikan berbagai aspek, seperti aspek budaya, sejarah dan ekonomi.

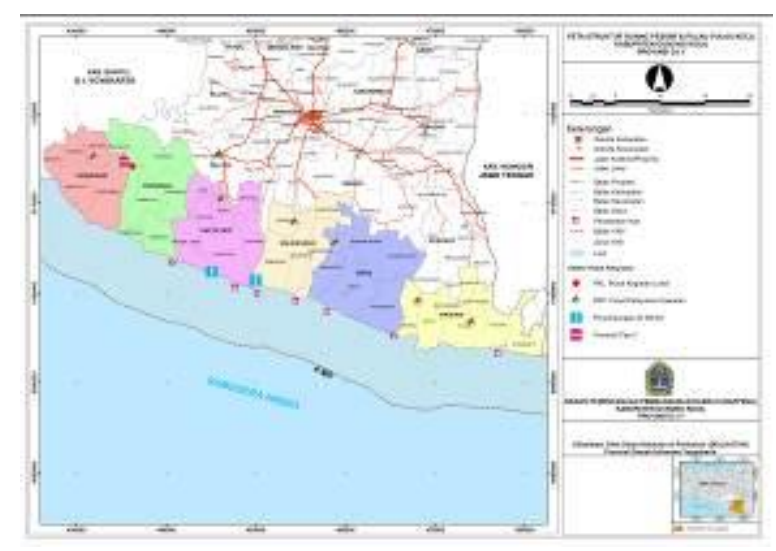

Gambar. 3. Struktur Ruang Wilayah Kabupaten Gunungkidul

(sumber : Bappeda Gunungkidul, 2016)

Pembangunan JJLS guna meningkatkan aksesibilats dan konektifitas wilayah selatan telah menempatkan wilayah pesisir Gunungkidul dalam hubungan antar wilayah, saat ini jaringan jalan tersebut telah menghidupkan distribusi barang dan jasa antar Propinsi Jawa Tengah, DIY, dan Jawa Timur. Secara bertahap, pesatnya pengembangan sektor pariwisata yang dalam beberapa tahun terakhir membuat wilayah pesisir Kabupaten Gunungkidul menjadi salah satu pilihan destinasi wisata secara regional. Hal ini tentunya menentukan strategi pembangunan dan penataan ruang wilayah, dimana wilayah pesisir hendaknya dipertimbangkan untuk 
dapat berfungsi sebagai wilayah yang mempunyai layanan lebih luas.

Pendekatan pembangunan berbasis nilai lokal (indigenous knowledge) dapat diwujudkan bersinergi dengan penataan ruang wilayah. Sebagai contioh, dalam dokumen RTRW Kabupaten Gunungkidul, Kecamatan Panggang berfungsi sebagai Pusat Kegiatan Lokal (PKL), tetapi di masa mendatang kawasan Panggang dan Purwosari dapat dikembangkan untuk melayani wilayah selatan Kabupaten Bantul dan Gunungkidul apabila melihat potensi perkembangan KSP I dan meningkatnya fungsi JJLS. Kawasan ini berdekatan dengan obyek wisata Pantai Parangtristis, Parangkusumo, dan Makam Raja Imogiri yang berpotensi untuk dikembangkan sebagai destinasi wisata minat khusus berbasis budaya. Hal ini juga didorong dengan adanya status DIY sebagai daerah istimewa dengan Undang-Undang Nomor 13 tahun 2012 tentang Keistimewaan DIY yang memungkinkan pemerintah daerah untuk mengembangkan wilayah berbasis nilai budaya lokal.

Upaya peningkatan layanan dalam hierarki struktur ruang juga dapat dilakukan di wilayah Kecamatan Girisubo, yang saat ini berfungsi sebagai Pusat Pelayanan Kawasan (PPK). Adanya pelabuhan perikanan pantai Sadeng dapat menjadi pintu masuk peningkatan fungsi kawasan. Pembangunan infrastruktur pelabuhan, pengembangan kawasan minapolitan, dan pengembangan JJLS akan membawa kawasan Sadeng menjadi sentra perikanan modern. Hal ini dapat meningkatkan fungsi layanan Kecamatan Girisubo sebagai penghubung wilayah tenggara Kabupaten Gunungkidul dengan Kabupaten Wonogiri dan Pacitan.

Proses pelibatan masyarakat dalam perencanaan tata ruang guna mendukung pembangunan wilayah, dapat dilakukan melalui beberapa langkah :

a. Menempatkan masyarakat sebagai pelaku.

b. Memfasilitasi masyarakat seagai pelaku yang memiliki pengetahuan akan kearifan lokal keberagaman budaya.

c. Mendorong agar stakeholder mampu bertindak secara transparan, akuntabel, dan professional.

d. Mendorong penguatan kelembagaan yang mewadahi berbagai aspirasi dari berbagai stakeholder.

Proses tersebut dapat dipadukan dengan nilai kearifan lokal yang tumbuh dalam budaya masyarakat Jawa untuk menumbuhkan kesadaran akan arti pentingnya memelihara nilai budaya sekaligus memberikan karakteristik yang unik dan berbeda dengan wilayah lain. Keistimewaan yang dimiliki oleh Daerah Istimewa Yogyakarta tidak bisa dilepaskan dengan keberadaan nilai-nilai filosofi dan budaya antara lain Hamemayu Hayuning Bawana (memperindah keindahan dunia, selaras dengan konsep ekologis), Sangkan Paraning Dumadi (mengenal hakekat manusia dan tujuan hidupnya), dan Manunggaling Kawula Gusti-Gusti Kawulo (hubungan antara masyarakat dan pemimpin dalam kehidupan, manifestasi hubungan sosial manusia).

\section{SIMPULAN}

Pola pemanfaatan ruang di wilayah pesisir Kabupaten Gunungkidul dipengaruhi oleh pola aktifitas masyarakat. Dikotomi ruang tradisional dan modern menghadirkan karakteristik tersendiri pada tiap-tiap kuadran. Karakteristik pada tiap kuadran memberikan gambaran akan potensi pengembangan wilayah pesisir Kabupaten Gunungkidul. 


\section{DAFTAR PUSTAKA}

Bemmelen, van R., W, The Geology of Indonesia. Vol IA. Martinus Nijhoff. The Hague, 1949.

I Cahyadinata, Kesesuaian Pengembangan Kawasan Pesisir Pulau Enggano Untuk Pariwisata Dan Perikanan Tangkap. Jurnal AGRISEP, Vol. 9 No. 2, 2009.

R., Dahuri, Rais, J., Ginting, S. P., Sitepu, M. J. Pengelolaan Sumber Daya Wilayah Peisir Dan Lautan Secara Terpadu. PT Pradnya Paramita. Jakarta, 2008.

N Daldjoeni, Geografi Kota dan Desa. Alumni. Bandung, 1978.

A. Djunaedi,, Basuki, M. N. Perencanaan Pengembangan Kawasan Pesisir. Jurnal Teknologi Lingkungan, Vol. 3 No. 3, 2002. Gunungkidul Dalam Angka 2016. Badan Pusat Statistik Kabupaten Gunungkidul.

Rencana Pembangunan Jangka Menengah Kabupaten Gunungkidul 2016-2021. BAPPEDA Gunungkidul.

Rencana Pengembangan Investasi Jangka Menengah Kawasan Minapolitan Perikanan Tangkap Kabupaten Gunungkidul. Dinas Kelautan dan Perikanan Gunungkidul
Rencana Tata Ruang wilayah Kabupaten Gunungkidul. BAPPEDA Gunungkidul

E. Salim, Pembangunan Berkelanjutan : Mencari Format Politik. PT. Gramedia Pustaka Utama. Jakarta, 1992.

Statistik Pariwisata DIY, Dinas Pariwisata DIY, 2016.

M. P. Todaro, Pembangunan Ekonomi di Dunia Ketiga. Erlangga. Jakarta, 2000.

Undang-undang Nomor 26 tahun 2007 tentang Penataan Ruang.

Undang-undang Nomor 13 tahun 2012 tentang Keistimewaan Daerah Istimewa Yogyakarta

www.kbbi.kemdikbud.go.id/ diakses tanggal 25 November pukul o9.45

www.miezgination.com/ Telaah buku Development From Above or Below?/diakses tanggal 4 Desember 2017 pukul 12.30 WIB

www.yuswohady.com/Core Econominya Jokowi. diakses 25 November 2017 pukul 16.05 WIB

H. S. Yunus, Teori dan Model Struktur Keruangan Kota. Fakultas Geografi UGM, Yogyakarta, 1994.

O. A. Yoeti, Perencanaan \& pengembangan pariwisata. Jakarta: PT Pradnya Paramita, 2008. 